\section{Global Journal of Information Technology}

Volume 05, Issue 1, (2015) 01-09

a er center gjit

\title{
A comparison of si th grade middle school teachers perceived benefits of the implementation of one to one digital conversion of laptops in the classroom
}

Hale K Bevans, School of Teaching and Learning, Illinois State University, United States Kathr n D Donaldson School of Teaching and Learning, Illinois State University, United States

Adel T Al Bataineh School of Teaching and Learning Illinois State University, United States

\section{Suggested Citation}

Bevans, H., K., Donalds, K., D., \& Al-Bataineh, A., T. (2015). A comparison of sixth grade middle school teachers perceived benefits of the implementation of one to one digital conversion of laptops in the classroom. Global Journal of Information Technology. 5(1), 01-09.

Received 25 December, 2014; revised 04 February, 2015 
Bevans, H., K., Donalds, K., D., \& Al-Bataineh, A., T. (2015). A comparison of sixth grade middle school teachers perceived benefits of the implementation of one to one digital conversion of laptops in the classroom. Global Journal of Information Technology. 5(1), 0109.

\section{Introduction}

Districts across the country are now transitioning from traditional classrooms into digital classrooms that include several forms of technology. Many educators find it more useful to incorporate technology into the classroom providing the students with appropriate learning environments. Conversely, many students are so familiar with technology that incorporating it into the classroom can only provide them with more motivation and engagement.

Nowadays, many educators are using several forms of technology in their classrooms, some of which include: laptops, desktops, interactive whiteboards, iPads, Elmo document cameras, overhead projectors, and many more. Many of these forms of technology are "old school" in the eyes of students. Therefore, it is incumbent upon us to enhance their learning ability by providing them with up to-date technology that they can relate to in order to make their education more meaningful. As classroom teachers, we cannot be teaching students how to ride a horse at school but expect them to drive a car in the real world. It is unfair and irrational to think that we can continue to teach the same way we have for years. Students should be trained to use technology that is closely aligned with the technology they use in their daily lives. Consequently, most states and school districts across the nation are buying into the new digital classroom.

The school district that is participating in this study made a decision to embrace the idea of transforming its classrooms into digital classroom. One of the most recent innovations that is being implemented in the school district is the one to one digital conversion for grades three to twelfth. The first round of implementation started in 2012-2013. Each student in sixth grade and incoming freshman students received a laptop. Consequently, the purpose of this study was to compare feedback and gain a better understanding of sixth grade middle school teachers' perceived benefits of the implementation of one to one digital conversion of laptops in the classroom. The feedback and data we receive from this study would benefit educators from all levels of education. Educators can get a better feel for what problems may occur during the implementation process of technology as well as understanding what types of technologies may have a more positive impact on motivating students.

\section{Literature Revie}

The current student generation is continuously exposed to technology which is an integral part of their digital lives [3]. Students are using a variety of technology forms from the internet to iPads to laptops. New research by Donovan, Green, Hartley (2010) [2] reported that more student engagement occurred and less off task behaviors were due to laptops being fully implemented into a classroom. In addition, they found that access to technology increases the motivation; however the results indicated that the use of technology was not beneficial for academic support.

A study by Wetzel and Marshall (2012) [6] reported that participants developed special expertise in the management of students and the technologies. One participant used technological pedagogical knowledge to direct student use of technology in ways that allowed the class to run smoothly without losing time to technology related distractions. The focus remained on learning the content area outcomes.

Another study discussed the importance of professional training prior to the implementation of 1:1 digital laptop conversion [1]. The purpose of this qualitative case study design was to document typical use of 1:1 computing in two middle schools focusing on the added value and unique challenges this initiative presents. The results show that teachers have found that the uses of laptops have given them greater access to up to-date instructional content in the form of online and computer based resources. Access to more technology has also caused a change in the teaching of students. Several teachers in the study reported that they are designing lessons that are more student-centered and have more of a constructivists approach allowing less lecturing and more facilitating or guiding students through the learning process. Laptops not 
Bevans, H., K., Donalds, K., D., \& Al-Bataineh, A., T. (2015). A comparison of sixth grade middle school teachers perceived benefits of the implementation of one to one digital conversion of laptops in the classroom. Global Journal of Information Technology. 5(1), 0109.

only can add value to the teaching and learning process but can also contribute to challenges with classroom management problems. The presence of 1:1 laptops does not automatically add value to high quality or effective teaching and learning. In order to create effective learning environments, teachers need opportunities to learn what instruction and assessment practices, curricular resources, and classroom management skills work best in a 1:1 student to laptop classroom setting. Furthermore, professional development could help teachers understand the benefits of student-centered learning environments [1].

In addition, Dexter \& Heinecke explained that the 1:1 implementation of the laptops contributes to classroom management problems. Along with classroom management, professional development was lacking to provide the teachers with ample support to incorporate this form of technology into their classrooms. The teachers said it was important to have professional development not only for them, but for the technology specialists as well. After the teachers are provided with ample information and professional development trainings preparing them for the digital conversion, they are now better prepared for the 1:1 digital conversion.

Shapley, Sheehan, Maloney \& Caranikas-Walker (2011) [5] examined the implementation of laptops for teachers and students in 21 middle schools at the 6th to 8th grades level. This implementation was completed by using a hierarchical linear model. This model was called the technology immersion program. There were both control schools and immersion schools which were involved in this process.

There were four focus areas which were taken into consideration during the implementation of the laptops within the classrooms. Those areas include: 1 . Technology immersion assumes effective technology use in schools and classrooms demands a comprehensive approach which requires technology to have a large amount of access, 2. the technology immersion increased access use of technology in schools with adequate and pedagogical support, 3 . this model assumes that teachers will need professional development in order to make this program run effectively, and 4. technology needs to support the curriculum using digital resources which should be available for teachers [5].

The core teachers within the classroom were assigned specific technology applications. Fewer of the applications were used in the immersion schools than the control schools. Within the immersion group, the small groups saw growth yearly. In the control group, the opposite results occurred. There was less group activity taking place. The control group used a traditional approach to teaching technology, while the immersion group applied more integrated technology into their schools. The immersion group which integrated it within the entire school noticed greater progress, students attended school less regularly, more access was provided to computers, more interaction with peers, TAKS scores increased, and an increase in academic achievement. Overall, there was much more success regarding the immersion school than the control schools. While these laptops are being integrated within the classroom, it is important as educators to take into consideration student motivation [5].

A study conducted by Liu (2011) aimed at examining middle school students' learning and motivation as they engaged in a new media enriched problem-based learning environment for middle school science. The researchers investigated the effect of a new media environment on sixth graders' science learning, their motivation, and the relationship between students' motivation and their science learning. The researchers used a media enhanced PBL environment known as Alien Rescue to engage students in solving complex problems while learning about the solar system and the process of scientific inquiry.

The sample in Liu's study consisted of sixth graders (220) from a middle school in a southwestern US city, 119 = female students, 101 = male students, in regular education classes. Both qualitative and quantitative data was collected from two different sixth grade classrooms for three weeks during the daily 45-minute science classes. Learning performance was measured by students' understanding of the various scientific concepts introduced in Alien Rescue. A 20 item test was administered both pre and post the use of Alien Rescue. A 
Bevans, H., K., Donalds, K., D., \& Al-Bataineh, A., T. (2015). A comparison of sixth grade middle school teachers perceived benefits of the implementation of one to one digital conversion of laptops in the classroom. Global Journal of Information Technology. 5(1), 0109.

motivation questionnaire was also given using a Likert scale. Six short answer questions were also given to the students.

The correct responses in the science knowledge test increased significantly from pretest to posttest for both male and female students and a small but significant difference was observed between males and females. About 180 students responded to the six open-ended questions giving a variety of written answers that ranged from elaborate to terse, from effusively positive to unquestionably negative. Student sentiment in general was that mostly the students had a fun experience interacting with the Alien Rescue curriculum [4].

The researcher's findings from both the qualitative and the quantitative data showed that both male and female students significantly increased their science knowledge from pretest to posttest after using Alien Rescue. The sixth graders were able to articulate science concepts they had learned when answering the short answer questions. The Alien Rescue was used as more of a self-paced instruction where teacher intervention was minimal. This showed that students acquired understanding of the scientific concepts through self-directed learning, classroom discussions, and peer research. The majority of the sixth grade students were motivated to use Alien Rescue. Research has shown that motivated students are more likely to persist in difficult situation and approach challenging tasks more eagerly than their less motivated peers. Such students would be motivated to solve problems when they are challenged and have the control of their own learning process [4].

The idea of using a media enriched problem based learning environment sounds extremely motivating. Students needed to have their own computers in order to access the online problem based learning media known as Alien Rescue. This study's targeted district has gone to a one to one digital conversion this year with each sixth grader having his or her own laptop. Understanding more about flipped classrooms and new technology resources that allow students to take control of their own learning process is intriguing and encouraging as a teacher. The most interesting factor from this study is how such technology can help turn the classroom into more of a student-centered atmosphere where students are self-directing their own learning and discovering new ways to problem solve. In summary, the research above provides us with optimal information proving that it is important to incorporate professional training for teachers before and during the implementation of 1:1 digital conversion into the classroom.

\section{Methodolog}

This study used a mixed design method. The purpose of the study was twofold: (1) to compare feedback and gain a better understanding of how sixth grade middle school teachers go through a one to one digital conversion with laptops and (2) investigate the advantages and disadvantages of this technology in the classrooms.

\subsection{Research Questions}

This study surveyed sixth grade teachers and was guided by the following questions:

1. How do middle school teachers incorporate technology into their classrooms?

2. What problems have occurred during the implementation process of the laptops?

3. What types of technology or online resources seem to motivate students?

4. Was there enough professional development support given to learn about the new technology and how to implement it into the classroom?

\subsection{Participants}

The participants in this study consisted of forty sixth grade educators in a school district in 
Bevans, H., K., Donalds, K., D., \& Al-Bataineh, A., T. (2015). A comparison of sixth grade middle school teachers perceived benefits of the implementation of one to one digital conversion of laptops in the classroom. Global Journal of Information Technology. 5(1), 0109.

central Illinois. There were approximately 1,004 sixth grade students who made up the sample school district. This school district is considered to be urban and consists of a variety of ethnic and racial backgrounds of students. According to the Illinois District Report Card 2011, the school district consists of $69.6 \%$ White students, $11.8 \%$ Black students, $6.8 \%$ Hispanic students, 6.2\% Asian students, $0.2 \%$ Native Hawaiian or Pacific Islander students, $0.3 \%$ American Indian students and $5.1 \%$ of two or more races. Students who come from low income families make up $28 \%$ of the students attending in the school district. The district has an extremely high parental contact percentage of $99 \%$. Parental contact includes parents who are involved in parentteacher conferences, parental visits to the school, school visits to home, telephone conversations and written correspondence. The average class size for the sixth grade classes in the school district is around 23.5 students.

\subsection{Instrumentation}

The instrument consisted of a five-point Likert scale survey that was developed by the researchers. The instrument used three scales. The first scale was used to address acquired computer skills as well as computer training skills. It ranged from $1=$ not at all, $2=$ to a small extent, $3=$ to a moderate extent, $4=$ to a great extent and $5=$ entirely. The second scale was used to address the integration of technology in the classroom. It ranged from $1=$ not at all, $2=$ once a month or less, $3=$ once a week, $4=$ several times a week and $5=e v e r y$ day. The third scale was used to addresses student motivation in the classroom. It ranged from $1=$ strongly disagree, $2=$ disagree, $3=$ neutral, $4=$ agree and $5=$ strongly agree.

This self-made survey was made up of several categories. The first category consisted of a demographic section that included gender, highest degree earned, teaching experience and the age of the educators. The second category focused on the preparation for one to one digital conversion separating the questions into three different parts. Part A for the second category consisted of six questions focusing on the teacher's acquired computer skills through what type of training. Part B for the second category consisted of two questions focusing on the computer training and skills which were influenced based on the result of what type of training. Part $\mathrm{C}$ for the second category consisted of two questions focusing to what extent different types of computer education would most benefit the educators. The second category of questions used "to what extent" type of Likert scale. The third category focused on the integration of technology into the classroom setting. There were eleven questions presented in this category. The fourth category focused on student motivation in the classroom. There were seven questions total in this category. The fifth category was an open-ended question where educators were asked to elaborate on the problems during the implementation of the one to one digital conversion in the classroom.

\section{Results}

The purpose of our study was to survey sixth grade teachers focusing on four specific questions about technology usage in their classrooms at a school district in central Illinois. The data shows that there are 40 certified sixth grade teachers in the district. Of the 40 certified teachers requested to take the survey, only $20(50 \%)$ responded.

\subsection{Research Question \#1: How do middle school teachers incorporate technology into their classrooms?}

Table one shows that teachers used different teaching modes in which technology was integrated in the classroom. The most common form of technology integration was the use of software such as the SMART board or Vision at $44.44 \%$. This technology was used daily to support whole group instruction. The highest percent of technology integrated into the classroom setting was technology used as a classroom presentation tool with over half of the 
Bevans, H., K., Donalds, K., D., \& Al-Bataineh, A., T. (2015). A comparison of sixth grade middle school teachers perceived benefits of the implementation of one to one digital conversion of laptops in the classroom. Global Journal of Information Technology. 5(1), 0109.

participants or $66.67 \%$ using it on a daily basis.

Table One: The percentage of Technology Integration in the Classroom

\begin{tabular}{llllll}
\hline Survey Question & Not at all & $\begin{array}{l}\text { Once a month } \\
\text { or less }\end{array}$ & Once a week & $\begin{array}{l}\text { Several times a } \\
\text { week }\end{array}$ & Daily \\
\hline Small group instruction & $5.56 \%$ & $38.89 \%$ & $16.67 \%$ & $33.33 \%$ & $5.56 \%$ \\
Whole group instruction & $0 \%$ & $5.56 \%$ & $11.11 \%$ & $38.89 \%$ & $44.44 \%$
\end{tabular}

Cooperative groups 
Bevans, H., K., Donalds, K., D., \& Al-Bataineh, A., T. (2015). A comparison of sixth grade middle school teachers perceived benefits of the implementation of one to one digital conversion of laptops in the classroom. Global Journal of Information Technology. 5(1), 0109.

Table Two: Participants responses regarding the impact of technology integration on student motivation

\begin{tabular}{|c|c|c|c|c|c|}
\hline Survey Question & $\begin{array}{l}\text { Strongly } \\
\text { Disagree }\end{array}$ & Disagree & Neutral & Agree & $\begin{array}{l}\text { Strongly } \\
\text { Agree }\end{array}$ \\
\hline $\begin{array}{l}\text { Technology seems to } \\
\text { increase student interest }\end{array}$ & $0 \%$ & $0 \%$ & $5.56 \%$ & $61.11 \%$ & $33.33 \%$ \\
\hline $\begin{array}{l}\text { Technology keeps students } \\
\text { on task }\end{array}$ & $0 \%$ & $5.56 \%$ & $22.22 \%$ & $66.67 \%$ & $5.56 \%$ \\
\hline $\begin{array}{l}\text { Technology helps students } \\
\text { work together }\end{array}$ & $5.56 \%$ & $5.56 \%$ & $16.67 \%$ & $66.67 \%$ & $5.56 \%$ \\
\hline $\begin{array}{l}\text { Technology improves } \\
\text { students' } \\
\text { assignments/projects } \\
\text { completion }\end{array}$ & $0 \%$ & $0 \%$ & $38.89 \%$ & $50 \%$ & $11.11 \%$ \\
\hline $\begin{array}{l}\text { Technology increases } \\
\text { students' performance on } \\
\text { tests and projects }\end{array}$ & $0 \%$ & $5.56 \%$ & $38.89 \%$ & $50 \%$ & $5.56 \%$ \\
\hline $\begin{array}{l}\text { Technology increases } \\
\text { students' attention span or } \\
\text { focus }\end{array}$ & $0 \%$ & $11.11 \%$ & $16.67 \%$ & $55.56 \%$ & $16.67 \%$ \\
\hline $\begin{array}{l}\text { Technology helps students } \\
\text { become independent } \\
\text { learners }\end{array}$ & $0 \%$ & $0 \%$ & $27.78 \%$ & $55.56 \%$ & $16.67 \%$ \\
\hline
\end{tabular}

4.4. Research Question \#4: Was there enough professional development support given to learn about the new technology and how to implement it into your classroom? Please elaborate on your positive and most beneficial professional development classes.

The sixth grade teachers found that interaction with other faculty and staff members was the most common and effective form of acquiring computer skills. The least effective form of acquiring computer skills was through the first year teacher orientation training as well as late start days being the least helpful forms of training. (Table Three)

Table Three: Participants responses regarding how they acquired technology skills

\begin{tabular}{|c|c|c|c|c|c|}
\hline Survey Question & Not at all & $\begin{array}{l}\text { To a small } \\
\text { extent }\end{array}$ & $\begin{array}{l}\text { To a moderate } \\
\text { extent }\end{array}$ & $\begin{array}{l}\text { To a great } \\
\text { extent }\end{array}$ & Entirely \\
\hline $\begin{array}{l}\text { My undergraduate or } \\
\text { graduate coursework }\end{array}$ & $27.78 \%$ & $22.22 \%$ & $38.89 \%$ & $11.11 \%$ & $0 \%$ \\
\hline Teacher Institutes & $5.56 \%$ & $33.33 \%$ & $33.33 \%$ & $27.78 \%$ & $0 \%$ \\
\hline Late Start Days & $27.78 \%$ & $72.22 \%$ & $0 \%$ & $0 \%$ & $0 \%$ \\
\hline $\begin{array}{l}\text { First Year Teacher } \\
\text { Orientation Training }\end{array}$ & $66.67 \%$ & $27.78 \%$ & $5.56 \%$ & $0 \%$ & $0 \%$ \\
\hline $\begin{array}{l}\text { Interaction with } \\
\text { faculty/staff }\end{array}$ & $0 \%$ & $5.56 \%$ & $33.33 \%$ & $61.11 \%$ & $0 \%$ \\
\hline Self-training & $0 \%$ & $11.11 \%$ & $44.44 \%$ & $44.44 \%$ & $0 \%$ \\
\hline
\end{tabular}

Half of the participants or $50 \%$ agreed that the administration both supported the use of technology training and encouraged the use of technology in the classroom at their middle schools (Table Four). 
Bevans, H., K., Donalds, K., D., \& Al-Bataineh, A., T. (2015). A comparison of sixth grade middle school teachers perceived benefits of the implementation of one to one digital conversion of laptops in the classroom. Global Journal of Information Technology. 5(1), 0109.

Table Four: Preparation for One to One Digital Conversion

\begin{tabular}{llllll}
\hline Survey Question & Not at all & $\begin{array}{l}\text { To a } \\
\text { small } \\
\text { extent }\end{array}$ & $\begin{array}{l}\text { To a } \\
\text { moderate } \\
\text { extent }\end{array}$ & $\begin{array}{l}\text { To a } \\
\text { great } \\
\text { extent }\end{array}$ & Entirely \\
\hline $\begin{array}{l}\text { The administration support for } \\
\text { technology related training. }\end{array}$ & $5.56 \%$ & $5.56 \%$ & $33.33 \%$ & $50 \%$ & $5.56 \%$ \\
$\begin{array}{l}\text { The administration actively } \\
\text { encourages the use of technology in } \\
\text { the classroom. }\end{array}$ & $0 \%$ & $11.11 \%$ & $27.78 \%$ & $50 \%$ & $11.11 \%$ \\
\hline
\end{tabular}

The most beneficial type of computer education according to $77.78 \%$ of the participants would be specialized training on integrating technology into the classroom. Understanding the technology is one thing but learning how to actually incorporate such technology in the classroom is another thing. Technologies placed in the classrooms do not make the students smarter. It takes specific skills of the teachers to be able to incorporate such technologies in the classroom to make more advanced and beneficial learning to occur (Table Five).

Table Five: Participants responses regarding the need of for technology training

\begin{tabular}{llllll}
\hline Survey Question & Not at all & $\begin{array}{l}\text { To a small } \\
\text { extent }\end{array}$ & $\begin{array}{l}\text { To a moderate } \\
\text { extent }\end{array}$ & $\begin{array}{l}\text { To a great } \\
\text { extent }\end{array}$ & Entirely \\
\hline $\begin{array}{l}\text { Specialized training on } \\
\text { integrating technology } \\
\text { into the classroom }\end{array}$ & $0 \%$ & $0 \%$ & $11.11 \%$ & $77.78 \%$ & $11.11 \%$ \\
$\begin{array}{l}\text { Specific applications (e.g. } \\
\text { CMS training, VISION, }\end{array}$ & $0 \%$ & $11.11 \%$ & $38.89 \%$ & $44.44 \%$ & $5.56 \%$ \\
Mastery Manager) & & & & & \\
\hline
\end{tabular}

\section{Discussion and Implications}

As we revisit the purpose of this study, we sought to answer a variety of questions. The first question was how do middle school teachers incorporate technologies into their classrooms? This research identified a common trend among all teacher participants. Teachers used technology typically during whole group instruction and independent learning as form of classroom presentations or for use with specific software such as (SMART or VISION). This finding is consistent with previous research reviewed in this study.

Research participants agreed (50\%) or more that technology provides much needed motivation for students at the middle school level when working with peers. The benefits include, helping them staying on task while on assignments/projects and during tests, improving their attention span, and helping them become more independent learners. This is consistent with Liu (2011) [4] study findings. Liu stated that research has shown that motivated students are more likely to persist in difficult situation and approach challenging tasks more eagerly than their less motivated peers. Students would be motivated to solve problems when they are challenged and have the control of their own learning process. Technology does motivate students in a variety of ways and it is significantly expressed within our results.

With regards to the research question, what problems have occurred during the implementation process of the laptops, we found that the main concerns that participants had were the issues with the internet connection and the laptops equipment. Participants stated that the equipment was in need of continued repairs. Previous research showed similar results in that participants had issues with laptop batteries. However, previous research indicated very little issues with wireless connections in comparison to this study's findings. 
Bevans, H., K., Donalds, K., D., \& Al-Bataineh, A., T. (2015). A comparison of sixth grade middle school teachers perceived benefits of the implementation of one to one digital conversion of laptops in the classroom. Global Journal of Information Technology. 5(1), 0109.

We also found that professional development during the implementation process of the one to one digital conversion of the laptops was primarily learned through a specified training. $78 \%$ of the participants indicated that training such as VISION or Mastery Manager came from a specific training provided by the district to prepare them for the digital conversion.

This study's findings are consistent with previous research found in Wetzel and Marshall's study. Specifically, teachers were implementing what they could, but focusing on the content areas mostly. Also students play a major role in aiding the teacher in technology implementation and troubleshooting. Wetzel and Marshall stated that whatever teachers could not figure out, the students would more than likely be able to figure out, this lead to more of a constructivist approach to learning. The results of this study are similar to previous research in that most school districts provide a briefing on the implementation of technology with little professional development.

The findings from this study covered four areas. The first area was whether the district participating in this study provided enough professional development while implementing the one to one digital conversion into the school district. The results support the fact that limited professional development was provided for the teachers to implement one to one digital conversion properly within their classrooms. Also, the results provided information on what motivates students the most and how the laptops are mainly used within the school district. The results also showed that most of the problems of the one to one digital conversion were the internet connection and equipment intermittent failures.

Based on the research findings, this current study reached the following implications: First, the next time a form of technology is implemented, it would be best if there would be a sufficient internet connection accessible for participants. In order to make the most of the

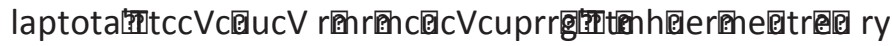

